\title{
TRANSFORMASI WAWASAN DUNIA MARAPU: TANTANGAN PEMBINAAN WARGA GEREJA DI SUMBA
}

\author{
Johanis Putratama Kamuri \\ Sekolah Tinggi Teologi Reformed Injili Internasional \\ Email: tama.kamuri@gmail.com
}

\begin{abstract}
The spirituality of some Sumbanese Christians is characterized by Marapu, not Christianity. This was influenced by their religious commitment to Marapu.Through a mixed method approach, this study shows that Marapu's worldview is a major force, which shapes the culture and religious commitment of Sumbanese. The principles in the worldview of Marapu are the main protocols in understanding reality, including Christian principles. This is a challenge for the church in Sumba in fostering its members. Based on Romans 12:1-2 and Philippians 4:8-9 it will be shown that the direction of church service and the fostering of church members is the transformation of worldview. This transformation must be based on biblical principles. The impact is a biblical and moderate cultural transformation.
\end{abstract}

Key Words: Marapu, Culture, Worldview Transformation, Biblical and Moderate Transformation.

\begin{abstract}
ABSTRAK: Sebagian orang Kristen Sumba memiliki spiritualitas yang berciri Marapu, bukan Kristen. Ini dipengaruhi oleh komitmen religiusnya terhadap Marapu. Melalui mixed method approach, penelitian ini menunjukkan bahwa wawasan dunia Marapu adalah kekuatan utama, yang membentuk budaya dan komitmen religius orang Sumba. Prinsip-prinsip dalam wawasan dunia Marapu penjadi protokol utama dalam memahami realita, termasuk prinsip-prinsip Kristen. Akibatnya adalah sinkretisme dan lemahnya komitmen terhadap prinsip-prinsip Kristen. Ini adalah tantangan dalam pembinaan warga gereja di Sumba. Berdasarkan Roma 12:1-2 dan Filipi 4:8-9 akan ditunjukkan bahwa arah pelayanan gereja dan pembinaan warga gereja adalah transformasi wawasan dunia. Transformasi ini harus didasarkan pada prinsipprinsip biblikal. Dampaknya adalah transformasi budaya yang biblikal dan moderat.
\end{abstract}

Kata Kunci: Marapu, Budaya, Transformasi Wawasan Dunia, Transformasi Biblikal dan Moderat.

\section{PENDAHULUAN}

Pulau Sumba disebut bumi Marapu karena kelimpahan jenis kekayaan budaya- seperti kain tenunan, budaya megalitik yang berusia ribuan tahun, dan berbagai ritual adat yang menarik wisatawan dari dalam negeri dan luar negeri - yang bersumber dari Marapu, pemujaan leluhur orang Sumba. Hingga saat ini, sebagian orang Sumba masih mempertahankan prinsip-prinsip yang diwariskan leluhur, yang mengatur seluruh siklus hidup sejak kelahiran hingga kematian. Sebab itu Marapu menjadi kekuatan untuk mempertahankan eksistensi kekayaan budaya di Sumba hingga saat ini. Ini membuat unsur-unsur yang asing terhadap budaya Marapu sulit mempengaruhi orang Sumba. Pengaruh Marapu merupakan tantangan serius bagi agama-agama asing yang masuk ke Sumba. Di Nusa Tenggara Timur (NTT), orang Sumba merupakan kelompok masyarakat yang paling sulit dipengaruhi oleh agama-agama tersebut (Webb,1986, p. 346-347). Marapu mampu bertahan menghadapi pengaruh unsur-unsur asing.

Ketika Kristen masuk ke Sumba, tahun 1876, Marapu merupakan tantangan serius bagi penginjilan dan pembinaan warga gereja. Marapu menyebabkan penolakan terhadap Kristen. Namun akhirnya Kristen memperoleh penerimaan sehingga antara tahun 1893 sampai tahun 1946 sudah ada 5.855 orang Kristen. Dengan berdirinya Gereja Kristen Sumba (GKS) pada tahun 1947, Kristen memperluas pengaruhnya. Tahun 1967, jumlah anggota GKS adalah 33.624 jiwa dan menjadi 146.551 jiwa pada tahun 1990 (Wellem, 2004, p. 353). Saat ini, jumlah anggota GKS diperkirakan lebih dari 400.000 jiwa.

Apakah pertumbuhan pesat secara kuatitatif adalah bukti bahwa orang Sumba telah dipengaruhi iman Kristen dan lepas dari pengaruh Marapu? Da- 
pat dikatakan bahwa pergantian agama tidak membuktikan perubahan komitmen religius dari Marapu menjadi Kristen. Hal ini dapat dipahami melalui beberapa situasi. Pertama, perkembangan Kristen berkaitan dengan politik pengakuan pemerintah Indonesia. Dalam TAP MPR No. IV/MPR 1978 tentang GBHN dan UU No.1/PNPS/1965, Pemerintah hanya mengakui dan menjamin hak penganut agama-agama yang diakui negara. Penganut aliran kepercayaan, seperti Marapu, didiskriminasi dan kehilangan hak-hak sipil. Bahkan sesudah tahun 1965, mereka yang tidak beragama dianggap simpatisan komunis (Vel, 2008, p. 39-40), sehingga hudupnya terancam. Penganut Marapu terpaksa menganut salah satu agama. Umumnya mereka memilih Kristen sehingga anggota gereja meningkat pesat (Vel 2008, p. 39; Wellem, 2004, p. 355).

Soeriadiredja (2013, p. 59) menyebut perpindahan agama dalam konteks diskriminasi (di Sumba) sebagai strategi budaya. Melaluinyajaminan negara atas hak dan hidup warga negara diperoleh sedangkan indentitas dipertahankan. Diskriminasi membuat perpindahan agama tidak selalu disertai perubahan komitmen religius. Fakta lain mendukung kesimpulan ini. Sebagian orang Kristen Sumba masih meyakini prinsip-prinsip Marapu dan terlibat aktif dalam ritual-ritual yang dilarang gereja (Tera dan Palar, 2018, p. 107). Spiritualitasnya masih berakar dan bercorak Marapu, bukan Kristen (Wellem, 2004, p. 356-358). Kuatnya komitmen religius terhadap $M a-$ rapu membuat sebagian orang Kristen Sumba sulit terlepas dari pengaruh Marapu. Sebab itu setelah reformasi, sebagian orang Kristen Sumba kembali menganut Marapu. Jadi komitmen religius terhadap Marapu merupakan penghalang bagi pembinaan terhadap warga gereja (yang bertujuan menghasilkan kualitas rohani yang baik dan perubahan komitmen religius).

Artikel ini bertujuan mengidentifikasi kekuatan utama yang mempengaruhi komitmen religius orang Sumba terhadap Marapu, sehingga arah pembinaan warga gereja (yang menghasilkan perubahan komitmen religius dan kehidupan Kristen yang ber- kualitas) bisaditemukan. Untuk itu masalah penelitian dirumuskan dalam dua pertanyaan: pertama, mengapa komitmen religius orang Sumba terhadap Marapu sangat kuat sehingga spiritualitas sebagian orang Kristen Sumba masih bercorak Marapu? Bagaimana gereja mengarahkan pembinaan warganya sehingga dapat menghasilkan perubahan komitmen religius dan kualitas kekristenan yang baik? Artikel ini menunjukkan bahwa wawasan dunia Marapu adalah penentu kuatnya komitmen religius orang Sumba terhadap Marapu, sehingga transformasi wawasan dunia adalah arah dan tantangan dalam pembinaan warga gereja di Sumba.

Tujuan dan masalah penelitian membedakan artikel ini dari penelitian-penelitian sebelumnya. Na$\operatorname{tar}$ (2019, pp. 101-120) mengkaji kearifan lokal Marapu dan mengkonstruksi teologi kontekstual untuk menjawab persoalan lingkungan di Sumba. Ia menggunakan prinsip Marapu tentang relasi manusia dan alam berdasarkan kesetaraan, keadilandan persaudaraan, bukan dominasi dan eksploitasi.

Strategi budaya orang Sumba, dalam menghadapi diskriminasi identitas oleh berbagai kekuatan eksternal, dideskripsikan Soeriadiredja (2013, pp. 5973). Prinsip-prinsip leluhur memandu strategi tersebut sehingga pergantian agama merupakan kompromi tanpa memusnahkan identitas asli sebagai orang Sumba. Penelitian lainnya menunjukkan bahwa prinsip-prinsip Marapu berperan sebagai konsep ekoteologis, yang mempengaruhi relasi harmonis orang Sumba dengan alam. Ini tampak pengaruh prinsipprinsip Marapu terhadap pemahaman dan respons masyarakat Wunga, Sumba Timur, terhadap bencana alam (Immanuel, 2013, p. 10-11). Kamuri (2020, pp. 73-98) mempersoalkan diskriminasi dan ketidakadilan terhadap penganut agama Marapu dalam aturanaturan hukum pemerintah Indonesia. Ia menuntut pengakuan utuh, terhadap identitas orang Sumba, dari pemerintah. Sementara itu Kleden (2017, pp. 24-34) menjelaskan jenis-jenis perkawinan dalam suku Wewewa di Sumba. Ia juga menggunakan teori resiprositas untuk memberi catatan kritis terkait belis, perkawinan dan berbagai sikap terhadapnya. 
Serupa dengan Kamuri, penelitian ini mengakui Marapu sebagai agama orang Sumba. Namun berbeda dari Kamuri yang berfokus pada diskriminasi terhadap penganut Marapu, penelitian ini berfokus pada pengaruh wawasan dunia Marapu pada komitmen religius orang Sumba. Sebab itu, penelitian ini berbeda juga dari Kleden yang hanya berfokus pada persoalan belis. Fokus pada wawasan dunia menjadikan penelitian ini serupa dengan penelitian Natar, Soeriadiredja dan Immanuel. Ketiganya menekankan prinsip-prinsip Marapu sebagai penentu pemahaman dan respons terhadap realita. Namun penelitian ini berbeda karena berfokus pada pembentukan wawasan dunia (berdasarkan prinsip-prinsip Marapu) yang mempengaruhi komitmen religius terhadap Marapu dan penentuan arah pembinaan warga gereja.

Selanjutnya kritik D.A. Carson terhadap pemikiran Niebuhr (tentang relasi Kristen dan budaya) dan ide tentang fondasi biblikal bagi relasi tersebut (Carson, 2018, pp. 52-77) digunakan untuk memahami arah bagi pembinaan warga gereja.

\section{METODE}

Penelitian ini menggunakan mixed method approach, yang mencari gambaran dan jawaban komprehensif tentang masalah penelitian melalui kombinasi paradigma penelitian yang berbeda-beda (Denscombe, 2014, p.146-148). Penelitian ini menggunakan paradigma teologis-filosofis dan bertumpu pada studi terhadap literatur yang relevan.

Pembacaan dilakukan dengan penalaran induktif, dengan dua langkah utama: pertama, kajian literatur untuk menemukan fakta atau masalah. Proses ini berguna dalam perumusan masalah penelitian, sebagaimana dipaparkan sebelumnya. Kedua, menjelaskan fakta atau masalah. Proses ini diawali dengan pendekatan filosofis untuk menunjukkan bahwa Marapu adalah agama sekaligus identitas budaya orang Sumba sehingga prinsip-prinsipnya membentuk wawasan dunia Marapu, kekuatan utama pembentuk komitmen religius orang Sumba terhadap Marapu.
Selanjutnya pendekatan teologis digunakan untuk merumuskan sikap Kristen terhadap budaya, menentukan arah pembinaan warga gereja, dan mengatasi masalah penelitian. Pemikiran Carson menjadi bingkai konseptual untuk mencapai tujuan ini. Sementara itu, arah pembinaan warga gereja di Sumba ditentukan melalui studi terhadap Roma 12:1-2 dan Filipi 4:8-9.

\section{HASIL DAN PEMBAHASAN}

\section{Marapu: Agama dan Identitas Budaya}

Agama memiliki ciri praktis dan substantif. Ciri pertama menegaskan peran agama dalam menjawab masalah penganutnya dan mengarahkan mereka pada makna hidup. Ciri kedua berkaitan dengan keyakinan tentang eksistensi dan peran realitas supranatural (Schilbrack, 2013, p. 293-296). Jadi agama berhubungan dengan komitmen pada prinsip religius dan ritual yang diberikan realitas supranatural, untuk menjawab kebutuhan dan menjamin hidup manusia. Wujud komitmen tersebut adalah pemujaan dan ketaatan pada prinsip-prinsip religius tersebut.

Marapu adalah pemujaan leluhur, kekuatan supranatural penentu kesejahteraan hidup melalui peran sebagai mediator dengan tuhan, melalui penyembahan terhadapnya dan melalui ketaatan pada prinsip dan ritual yang diturunkannya (Kleden, 2017, p. 61; Lado and Palar, 2018, p. 108). Maka Marapu memenuhi syarat untuk disebut agama.

Ini juga menunjukkan beberapa komponen pada Marapu. Pertama, keyakinan pada eksistensi tuhan dan leluhur (realitas supranatural). Ini petunjuk pada kebenaran klaim Carson (2018, p. 73) bahwa Allah, dalam konteks anugerah umum, memberi petunjuk pada eksistensi dan kehendak-Nya. Meski tidak merujuk pada Allah sejati, ini adalah konteks yang tepat bagi penginjilan dan penyataan kebenaran Allah (Kis. 17:22-34). Kedua, Marapu diyakini mampu menjamin hidup melalui kuasa, ritual dan prinsip yang diturunkannya. Prinsip dan ritual Marapu diyakini efektif menjamin kesejahteraan dengan menjaga relasi harmonis manusia dengan alam, 
sesama, tuhan dan leluhur (Tera and Palar, 2018, p. 107-108). Keyakinan ini bermuara pada komponen ketiga, komitmen religius yang tampak melalui pemujaan dan ketaatan pada leluhur maupun prinsip dan ritual yang diturunkannya. Komitmen religius membuat prinsip Marapu selalu berperan sebagai paradigma dalam memahami realita, termasuk prinsip-prinsip Kristen (Tera and Palar, 2018, p. 107).

Kehadiran unsur-unsur asing, seperti prinsipprinsip Kristen, mengancam hidup dan kesejahteraan karena bertentangan dengan otoritas Marapu maupun prinsip-prinsip yang diberikannya untuk menjamin kesejahteraan melalui relasi kosmik-harmonis. Karena perubahan mengganggu rasa aman, orang Sumba enggan meninggalkan Marapu. Sebagian orang Kristen Sumba menyelesaikan konflik prinsip Kristen dan Marapu melalui sintesa (sinkretisme) atau kembali ke agama Marapu.

Marapu muncul di Sumba dan identik dengan identitas orang Sumba, sehingga layak disebut sebagai agama asli (MacDonald, 2011, p. 814). Umumnya, agama-agama seperti ini merupakan fondasi indetitas masyarakat karena membentuk inti budaya yang dapat bertahan dari pengaruh globalisasi (Alybina, 2014, p. 89). Sebab itu produksi dan reproduksi budaya di Sumba berporos pada Marapu. Budaya yang ada di Sumba mengekpresikan keyakinan dan sistem nilai penentu identitas yang merekatkan orang Sumba tersebut.

Identitas budaya adalah keunikan karakter pembeda berbagai kelompok mayarakat. Keunikan dihasilkan oleh prinsip-prinsip budaya yang disadari dan diakui setiap anggota masyarakat, yang menjadi standar penerimaan dan penolakan terhadap anggota masyarakat (Owens, Robinson, and Smith-lovin, 2010, p. 491), dan yang mengarahkan hidup mereka. Umumnya, keunikan identitas juga dipahami oleh komunitas di sekitar masyarakat tersebut.

Dengan menyebut Marapu sebagai "agama kita" dan menjadikannya protokol kehidupan personal dan bermasyarakat (Soeriadiredja, 2013, p.60), orang Sumba menegaskan bahwa Marapu adalah identitas budayanya. Ini adalah pembeda orang
Sumba asli dari pendatang atau kelompok masyarakat lain di sekitar pulau Sumba. Beberapa implikasi dapat ditarik dari penjelasan tersebut. Pertama, prinsip-prinsip yang diyakini masyarakat menentukan keunikan identitas budaya. Maka identitas budaya orang Sumba dibentuk prinsip-prinsip Marapu yang diyakininya. Kedua, karakteristik unik tampak jelas karena prinsip-prinsip yang diyakini mengarahkan cara pikir dan diregularisasi dalam tindakan. Karena prinsip-prinsip Marapu mempengaruhi orang Sumba pada tataran kognitif dan praktis, maka Marapu tidak mungkin tidak menjadi identitas budaya mereka.

Prinsip-prinsip Marapu adalah inti agama, budaya dan identitas budaya orang Sumba sehingga mereka cenderung meyakini dan mempraktikkannya. Ini mengokohkan komitmen religius terhadap Mara$p u$. Prinsip-prinsip Kristen,yang eksternal terhadap Marapu, dipahami dan disesuaikan dengan prinsipprinsip Marapu. Melalui proses ini prinsip-prinsip Kristen akan ditolak bahkan dapat berfungsi untuk memperkuat keyakinan terhadap Marapu.

Ini adalah petunjuk pada beberapa hal. Pertama, budaya adalah eksternalisasi pikiran yang dicemari dosa dan perlawanan pada Allah, sehingga membutuhkan transformasi (Carson, 2018, p. 54-58, 65). Kedua, komitmen religius terhadap Marapu dikokohkan oleh keyakinan terhadap prinsip-prinsip religius dan kulutral Marapu dan penerapannya dalam keseharian. Prinsip-prinsip tersebut menjadi bingkai konseptual untuk memahami dan menguji segala sesuatu. Ini adalah petunjuk bahwa Marapu merupakan wawasan dunia orang Sumba.

\section{Marapu: Wawasan Dunia Orang Sumba}

Prinsip-prinsip agama suku berfungsi sebagai wawasan dunia yang membentuk budaya dan identitas masyarakat (Alybina, 2014, p. 89), sehingga prinsip-prinsip Marapu, yang diyakini dan dipraktikkan orang Sumba, akan menjadi wawasan dunia Marapu yang mengkondisikan bentuk budaya dan identitas budaya mereka.

Wawasan dunia (worldview) adalah skema konseptual penentu persepsi (Vaisey and Lizardo, 
2010, p. 1606) yang menentukan interpretasi terhadap realita dan mengkondisikan kecenderungan bahkan tindakan (Bruning and Lambe, 2009, p. 140141). Karena terbentuk dalam konteks sosial, wawasan dunia menjadi struktur virtual-kognitif yang juga bersifat historis (Demeter, 2012, p. 40-41).

Wawasan dunia memiliki tiga komponen yang saling terhubung (Schultz dan Swezey, 2013, p. $233,235,238$ ). Pertama, pranggapan-pranggapan yang diyakini sebagai kebenaran. Ini serupa dengan prinsip-prinsip Marapu yang oleh orang Sumba dipercaya begitu dana sebagai kebenaran. Kedua, penerapan pranggapan dalam tindakan. Contohnya adalah pola hidup yang disesuaikan pada prinsip-prinsip Marapu. Ketiga, kecondongan hati pada praanggapan yang diyakini benar dan tindakan yang distrukturkannya. Wawasan dunia mencondongkan masyarakat untuk meyakini praanggapan dan mempertahankan tindakan yang berkorespondensi dengan praanggapan tersebut.

Jadi wawasan dunia merupakan struktur dalam kognisi yang terbentuk dari prinsip-prinsip budaya, yang diyakini benar dan terus dipraktikkan masyarakat. Wawasan dunia menentukan arah hidup karena realita dipahami dan disesuaikan padanya. Akibatnya wawasan dunia mengkondisikan cara pikir, tindakan dan bentuk atau ekspresi budaya.

Wawasan dunia orang Sumba terbentuk dari prinsip-prinsip Marapu yang diyakini sebagai kebenaran dan yang diregularisasi dalam tindakan. Ini adalah wawasan dunia Marapu yang mengarahkan dua hal. Pertama, mengarahkan kecenderungan atau komitmen pada prinsip-prinsip Marapu. Kedua, mengarahkan cara pikir tindakan sesuai prinsip-prinsip Marapu. Sebab itu orang Sumba tidak dapat memahami dan meresponi realita di luar kategori-kategori yang disediakan Marapu (Kamuri, 2020, p. 83). Prinsip-prinsip Kristen dan budaya modern, contohnya, dipahami orang Sumba berdasarkan prinsipprinsip Marapu yang merupakan protokol utama (Tera dan Palar, 2019, p. 107).

Beberapa implikasi perlu ditekankan. Pertama, wawasan dunia terbentuk dari praanggapan yang diyakini dan diregularisasi dalam tindakan, sehingga bersifat religus sekaligus kultural. Kultural karena prinsip-prinsip pembentuk wawasan dunia bersumber dari budaya. Religius karena pada inti setiap wawasan duniaada keyakinan-keyakinan yang sangat mendasar. Kedua, wawasan dunia adalah paradigma pembentuk cara pikir, kecenderungan hati dan perilaku. Akibatnya manusia sulit bertindak berbeda dari wawasan dunia yang mengkondisikannya pada tataran kognitif dan praktis. Kategori-kategori Marapu menjadi ruang sekaligus batasan bagi cara pikir dan cara hidup orang Sumba (Kamuri, 2020, p. 83). Realita, termasuk Injil dan iman Kristen, senantiasa dipahami dan disesuaikan pada prinsip-prinsip Marapu. Ketiga, wawasan dunia dikokohkan oleh regularisasi praktik hidup yang dibentuknya. Ada hubungan timbal balik antara wawasan dunia dengan tindakan yang dihasilkannya. Makin sering pola hidup yang dihasilkan wawasan dunia Marapu dihidupi orang Sumba, eksistensi dan pengaruhnya menjadi semakin kokoh. Ini membuat sebagian orang Kristen Sumba, yang terus terlibat dalam berbagai ritual $M a$ rapu, tetap berakar dalam spiritualitas Marapu dan memiliki corak hidup yang berkarakter Marapu, bukan Kristen (Wellem, 2004, p. 356-358).

Ketiga implikasi tersebut dapat digunakan untuk memahami permasalahan penelitian. Iman Kristen sulit berakar dalam kehidupan orang Sumba, karena komitmen religiusnya distrukturkan wawasan dunia Marapu. Prinsipreligius dan kultural Marapu menjadi elemen utama pembentuk wawasan dunia Marapu. Konsekuensinya wawasan dunia Marapu menjadi kekuatan utama yang mengarahkan pikiran, komitmen dan tindakan orang Sumba. Dengan demikian orang Sumba akan meregularisasi tindakan yang berpadanan dengan prinsip-prinsip Marapu, sehingga eksistensi dan pengaruh wawasan dunia $M a-$ rapu makin dikokohkan.

Cara pikir dan cara hidup orang Sumba sulit dibentuk berdasarkan prinsip-prinsip Kristen, karena wawasan dunia Marapu mencondongkan komitmen religius mereka pada prinsip-prinsip Marapu dan berbagai tindakan yang dihasilkannya. Selain itu 
prinsip-prinsip Kristen selalu dipahami berdasarkan wawasan dunia Marapu (Wellem, 2004, p. 5,11) sebagai paradigma pemandu seluruh aspek hidup.

Situasi ini memiliki dua akibat. Pertama, tereliminasinya prinsip-prinsip Kristen yang tidak dapat disesuaikan pada wawasan dunia Marapu. Keyakinan bahwa leluhur merupakan mediator dan pelindung keturunannya membuat sebagian orang Kristen Sumba tetap memuja leluhur yang sudah meninggal. Bahkan otoritas para nabi dalam Alkitab disetarakan dengan otoritas leluhur, karena semua yang sudah matimenjadi Marapu (Tera dan Palar, 2018, p. 107). Ini membuat orang Sumba cenderung pada Marapu Sumba pemberi tradisi daripada Marapu Kristen pemberi Alkitab. Kedua, diakomodirnya ajaran-ajaran Kristen yang memperkuat komitmen pada Marapu. Cerita Alkitab tentang tulah belalang di Mesir diadopsi untuk meneguhkan pandangan bahwa pelanggaran terhadap prinsip-prinsip Marapu adalah penyebab hama belalang di Sumba. Sebelumnya, masalah ini tidak dapat dijawab oleh wawasan dunia Marapu (Immanuel, 2013, p. 153).

Penolakan terhadap prinsip-prinsip Kristen maupun sintesa prinsip-prinsip tersebut dengan $M a$ rapu akan memperkuat komitmen religius terhadap Marapu, sementara iman Kristen tidak dapat berakar dengan baik. Konflik antara wawasan dunia Kristen dan wawasan dunia yang terbentuk dalam budaya tertentu selalu menjadi pergumulan gereja (Carson, 2018, p. 63). Ini juga menjadi tantangan gereja di Sumba. Sebab itu, dalam pembinaan warganya, gereja harus merumuskan sikap terhadap budaya dan menemukan solusi bagi konflik wawasan dunia tersebut.

\section{Transformasi Biblikal dan Moderat: Tanggung Jawab Kristenterhadap Budaya}

Wawasan dunia yang menjadi antithesis wawasan dunia Kristen tidak dapat dilepaskan dari prinsip budaya pembentuknya. Pertanyaannya, "bagaimana seharusnya gereja bersikap terhadap budaya?" Isu inidapat dipahami melalui kritik Carson terhadap terhadap pemikiran Richard Niebuhr tentang orang Kristen dan budaya. Budaya adalah totalitas aktivitas manusia dan hasil-hasilnya (Niebuhr,1951, p. 32). Budaya adalah inti hidup, proses yang tak terpisahkan dari manusia. Sebelum manusia berdosa dan sebelum gereja menerima mandat Injil, Allah sudah menugaskan manusaia untuk memuliakan Dia melalui mandat budaya (Kej. 1:26-28).

Namun dosa membuat manusia melawan Allah melalui budaya. Akibatnya orang Kristen memberi respon berbeda terhadap budaya. Niebuhr (1951, p. 40-43) mengidealisasikannya dalam lima sikap. Pertama, menolak dan mengabaikan budaya yang dianggap beroposisi dengan iman. Kedua, menekankan supremasi budaya atas iman. Iman disesuaikan sepenuhnya pada budaya. Mirip dengan yang kedua, sikap ketiga menegaskan kesinambungan iman dan budaya, tapi menolak kemungkinan di mana manusia dapat menghasilkan budaya yang benar.

Sikap keempat menekankan dualitas iman dan budaya: keduanya merupakan otoritas yang harus ditaati meski saling bertentangan. Pembaruan relasi ini hanya dijumpai di akhir zaman (Niebuhr, 1951, p. 42-43). Sikap kelima mengakui peran Kristen sekaligus pengaruh dosa terhdap budaya. Gereja mentransformasi budaya melalui koversi unsur-unsur budaya dengan prinsip-prinsip iman (Niebuhr, 1951, p. 43). Bagi Niebuhr, sikap kelima merupakan sikap Kristen yang seharusnya terhadap budaya.

Carson mengajukan dua keberatan. Pertama, Niebuhr tidak memperhatikan prinsip-prinsip biblikal untuk posisinya. Kedua, tidak ada sikap ideal terhadap budaya karena sikap Kristen ditentukan oleh situasi dalam budaya yang dijumpai gereja (Carson, 2018, p. 44-45, 74). Solusi Carson adalah integrasi kebenaran biblikal yang termuat dalam lima sikap di atas. Kesesuaian dengan prinsip-prinsip Alkitab adalah tujuan utama. Selain mengakui eksistensi dan pengaruh dosa, Alkitab menjadikan inkarnasi, kehadiran Yesus di antara manusia, sebagai teladan tertinggi (Carson, 2018, p. 54-62). Gereja harus menyadari pengaruh dosa terhadap budaya tanpa terjebak dalam oposisi total iman dan budaya (sebagaimana tampak pada sikap pertama). Gereja tidak diarahkan 
pada penolakan terhadap budaya. Melalui teladan Yesus, gereja diarahkan untuk hadir dan menyatakan kerajaan Allah dalam budaya.

Agama kuno, seperti Marapu, dapat menyumbangkan berbagai hal yang penting bagi manusia sebagaimana diperjuangkan juga dalam Kristen dan modernisme (Laugrand,2012, p. 11). Ini tampak dalam penelitian Natar (2019, pp. 106-117) yang menunjukkan titik temu teologi Kristen dan kearifan lokal Marapu, yang berfungsi sebagai landasan bagi perpektif teologi kontekstual yang dapat menyelesaikan persoalan ekologis. Jadi budaya tidak perlu dihindari, karena pengaruh dosa tidak meniadakan kontribusinya bagi manusia secara teoritis dan praktis.

Orang Kristen memerlukan adaptasi kontekstual terhadap budaya. Adaptasi hanya dapat dilakukan jika orang Kristen memasuki dan memahami budaya (Anderson, 2010, p. 10). Tapi orang Kristen juga perlu mewaspadai dan mengkritisi budaya, sehingga adaptasi kontekstual tidak menjadi kompromi dengan dosa (Patterson, 2012, p. 57). Sikap terbuka dan waspada dibutuhkan karena pengaruh dosa terhadap budaya.

Tidak semua unsur budaya dapat diadopsi tanpa sikap kritis. Belis (mahar) adalah budaya umum di Sumba dan di NTT. Ini adalah simbol penghargaan pada mempelai perempuan dan keluarganya. Tapi praktik belis dapat berubah menjadi transaksi ekonomi. Akibatnya perempuan yang "lunas dibayar" sering mendapat perlakuan tidak layak. Kepekaan dan sikap kritis terhadap pengaruh dosa tidak ditemukan pada sikap kedua, dalam pemikiran Niebuhr.

Carson $(2018$, p. 73,76) juga menekankan prinsip kedaulatan Allah. Alkitab menegaskan Allah sebagai Pencipta berdaulat atas ciptaan. Allah meninggalkan petunjuk-petunjuk pada diri-Nya dalam semua budaya sehingga dunia tidak dapat meniadakan kemuliaan Allah di budaya. Prinsip biblikal ini tidak tampak dalam sikap ketiga dan keempat, yang diidealisasi Niebuhr. Bagi sikap ketiga, budaya yang benar tidak dapat dihasilkan manusia. Sementara yang keempat menekankan sikap pasif: tunduk pada otoritas budaya dan iman yang kontradiktif, sambil menanti pembaruan oleh Kristus di akhir zaman.

Kepekaan terhadap dosa tampak dalam dua sikap ini. Tapi keduanya mengabaikan kedaulatan dan kuasa Allah dalam mempertahankan hal-hal baik dalam budaya dan menghadirkan transformasi. Sebab itu keduanya tidak dapat meresponi panggilan untuk masuk dan metransformasi budaya. Muara pemikiran ini adalah pengabaian terhadap budaya atau sikap pasif, menerima pengaruh budaya tanpa sikap kritis. Ruang bagi sinkretisme menjadi sangat terbuka.

Niebuhr mengkritisi empat sikap pertama dan mendukung sikap kelima yang menekankan keterlibatan Kristen dalam budaya dan kewaspadaan terhadap dosa. Namun Carson mengkritisi Niebuhr yang menekankan transformasi melalui konversi setiap unsur budaya. Alkitab adalah otoritas utama dalam transformasi budaya, tapi ada unsur-unsur budaya yang berpadanan dengan Alkitab sehingga dapat diadopsi oleh Kristen (Carson, 2018, p. 65, 73). Ini adalah pengakuan terhadap kedaualatan Allah dan anugerah umum-Nya dalam setiap budaya.

Transformasi yang diagendakan Carson bersifat biblikal dan moderat. Moderat karena menyatukan kebenaran biblikal dalam lima sikap yang dipertentangkan Niebuhr, serta terbuka terhadap sumbangsih budaya yang tidak melawan prinsip Firman. Biblikal karena transformasi digerakkan dan didasarkan pada prinsip-prinsip Firman. Ini menyingkirkan apa yang tidak sesuai dengan Firman sebagai paradigma transformasi budaya.

Tiga asumsi penting harus diperhatikan orang Kristen (Yarnell III, 2012, p. 25). Pertama, budaya adalah berkat Allah, tapi juga dipengaruhi dosa. Kedua, sinkretisme atau kompromi adalah ancaman serius. Ketiga, panggilan untuk terlibat dalam budaya demi transformasi disertai peringatan untuk waspada terhadap budaya.

Transformasi biblikal dan moderat mengasumsikan ketiga prinsip tersebut. Transformasi biblikal dan moderat menuntut keterlibatan aktif: memasuki budaya dengan sikap kritis dan mempelajari bu- 
daya untuk beradaptasi secara kontekstual. Artinya gereja mengakomodir unsur-unsur budaya yang berpadanan dengan Firman, tapi menolak unsur-unsur yang bertentangan dengannya. Jadi transformasi biblikal dan moderat melibatkan pemahaman memadai terhadap budaya dan sikap kritis berdasarkan prinsip-prinsip Alkitab.

Transformasi biblikal dan moderat yang mendorong keterlibatan aktif dalam kebudayaan adalah panggilan gereja dan arah bagi pembinaan warga gereja. Ini merupakan panggilan dan arah pembinaan warga gereja di Sumba. Menjadi Kristen tidak berarti meninggalkan masyarakat dan budaya. Warga gereja perlu dibina dan diperlengkapi agar mampu mengenal, menguji dan mentransformasi budaya serta mempengaruhi masyarakat berdasarkan prinsipprinsip biblikal.

Tranformasi biblikal dan moderat menghindarkan gereja di Sumba dan warganya dari keterlibatan pasif: membiarkan diri dipengaruhi oleh prinsip-prinsip Marapu dan menyesuaikan diri padanya. Keterlibatan gereja adalah keterlibatan aktif. Nasihat Paulus dalam Roma 12:1-2 dan Filipi 4:8-9 dapat menjadi rujukan dalam partisipasi aktif gereja dan jemaat dalam masyarakat dan budaya.

\section{Tantangan dan Arah Pelaksanaan Pembinaan Warga Gereja di Sumba}

Meski memberi ruang bagi pengadopsian unsur-unsur budaya, transformasi biblikal dan moderat menjadikan prinsip-prinsip Alkitab sebagai paradigma bagi proses adaptasi. Sebab itu Carson (2018, p. 65) menegaskan bahwa Kristen tidak dapat mengadopsi unsur-unsur yang melawan Alkitab.

Budaya yang melawan otoritas Alkitab bersumber dari wawasan dunia yang melawan Alkitab. Maka titik awal tranformasi budaya adalah transformasi wawasan dunia. Penelitian ini merujuk Roma 12:1-2 dan Filipi 4:8-9 untuk menunjukkan panggilan Kristen untuk memasuki dunia dan budaya dengan wawasan dunia baru yang mempengaruhi cara hidup. Akan ditunjukkan pula bahwa perubahan wawasan dunia, dari Marapu menjadi Kristen (bibli- kal), adalah tantangan dan tujuan pembinaan warga Gereja di Sumba.

\section{Menentukan Arah Pembinaan Warga Gereja}

Meski segala otoritas di bumi (atas semua budaya) telah diserahkan pada Kristus, kerelaan untuk tunduk pada pemerintahan Kristus hanya ditemukan pada umat tebusan (Carson, 2018, p. 75). Sebagai ciptaan baru-sebagaimana diuraikan Roma 111 - orang Kristen, dari dan dalam budaya apapun, harus "mempersembahkan tubuh" pada Allah (Rm. 12:1-2) dengan hidup berdasarkan prinsip-prinsip Firman dalam dunia yang distrukturkan prinsip-prinsip budaya (Flp.4:8-9).

Kata "mempersembahkan" berkaitan dengan ibadah bait Allah, sehingga "mempersembahkan tubuh" berarti menyerahkan diri pada Allah untuk diatur dengan Firman (Nugroho, 2018, p. 190) dan diarahkan pada kesucian hidup (mematikan dosa). Namun orang Kristen tidak perlu menjauhi dunia dan budaya. Kata tubuh (Rm. 12:1) juga mengacu pada totalitas hidup manusia yang tidak dapat tidak berelasi dengan dunia (Smiga, 1991, p. 267). Paulus menegaskan panggilan Kristen untuk hidup suci dan memuliakan Allah tanpa memutuskan relasi secara total dengan dunia dan budaya.

Bagaimana orang Kristen memuliakan Allah dalam budaya tanpa memutuskan relasi dengannya? Paulus menggunakan kata "dunia” (Rm. 12:2) yang mencakup budaya manusia dan prinsip-prinsip yang diturunkannya (Yarnell III, 2012, p. 23). Bagi Paulus, manusia dapat digerakkan oleh dua otoritas: Firman atau budaya. Tapi Paulus memanggil gereja untuk melayani tujuan-tujuan Allah dalam budayanya (Sumarto, 2019, p. 66).Ini berarti gereja dapat berelasi dengan dunia dan budaya dengan arah yang baru: penyesuaian diri dengan otoritas Firman dan tidak digerakkan oleh prinsip-prinsip budaya yang didalamnya mereka hidup.

Tetapi ini tidak berarti orang Kristen harus menyingkirkan semua unsur budaya. Filipi 4:8 membicarakan sejumlah kebajikan moral (virtue) yang harus dipikirkan dan dihidupi orang Kristen. Semua- 
nya merupakan shared knowledge, kebajikan yang terdapat dalam ajaran Kristen maupun filsafat moral popular, yang telah diketahui jemaat sebelum menjadi Kristen (Snyman, 2007, p. 238-241). Untuk memuliakan Allah dalam budaya, Paulus mendorong jemaat menghidupi prinsip-prinsip budaya yang berpadanan dengan Firman. Jadi unsur-unsur budaya yang tidak melawan Alkitab dapat dipertahankan.

Tujuan utama transformasi biblikal dan moderat adalah masuk dalam budaya untuk menyatakan otoritas Kristus atas budaya dengan menghadirkan prinsip-prinsip kerajaan Allah dan menyesuaikan diri pada prinsip-prinsip tersebut (bd. Carson (2018, p. 75). Tujuan dicapai dengan menghidupi Firman dan prinsip budaya yang berpadanan dengannya, serta meninggalkan prinsip-prinsip budaya yang melawan Firman.

Transformasi biblikal dan moderat, yang mengubah hidup melalui penyesuaian diri pada prinsip Firman, dicapai melalui transformasi cara pikir (Rm. 12:2). Sebab itu Filipi 4:8-9 menggunakan retorika yang menekankan pergeseran dari cara pikir yang tidak seharusnya menjadi cara pikir yang seharusnya (Holloway, 1998, p. 90). Jadi kekuatan utama yang memungkinkan perubahan hidup adalah adalah transformasi cara pikir atau transformasi wawasan dunia.

Jemaat Roma dan Filipi adalah Yahudi dan non-Yahudi. Wawasan dunianya dibentuk oleh prinsip-prinsip religius (Yahudi) dan moral-filosofis ( $Y u-$ nani), yang telah menghasilkan dua budaya yang agung (walau memiliki banyak persoalan spiritual). Meski demikian gereja diperingatkan agar tidak "menjadi serupa dengan dunia." Ini adalah peringatan untuk tidak aktif menyesuaikan diri pada prinsipprinsip budaya yang melawan Firman dan tidak membiarkan diri dipengaruhi prinsip-prinsip tersebut (pasif). Dua cara hidup ini menjadikan jemaat serupa dengan dunia, yang melawan Allah.

Dua kelompok orang Kristen, yang muncul dari dua budaya agung yang berbeda, dinasehati untuk waspada terhadap pengaruh prinsip-prinsip kultural, yang mengarahkan cara pikir dan cara hidup se- belum mereka menjadi Kristen (Boice, 2005, p. 1523, 1539). Mereka tidak perlu mengabaikan budaya. Mereka juga tidak boleh menyesuaikan diri pada prinsip-prinsip budaya tanpa sikap kristis.

Dua kelompok Kristen ini harus mewaspadai cara pikir dan cara hidup yang bersumber dari wawasan duniayang melawan Firman. Keduanya dinasihati untuk menundukkan pikiran dan tindakan pada otoritas yang sama: prinsip-prinsip Firman pembentuk wawasan dunia Kristen. Dengan demikian mereka memiliki wawasan dunia yang sama, yang membentuk kesamaan identitas mereka sebagai orang Kristen. Jadi gereja harus meninggalkan wawasan dunia lama (yang distrukturkan prinsip-prinsip budaya yang melawan Firman) lalu mengadopsi wawasan dunia Kristen (yang dibentuk prinsip-prinsip Firman). Ini mengandaikan transformasi wawasan dunia dan kemampuan membedakan prinsip-prinsip Firman dan prinsip-prinsip budaya.

"Berubahlah oleh pembaharuan budi" (Rm. 12:2) menekankan proses pembaharuan cara pikir, sehingga cara hidup menjadi berbeda dari dunia (Dwiraharjo, 2018, p. 4). Ini adalah transformasi wawasan dunia, sebab pola hidup yang berbeda dengan dunia hanya dihasilkan oleh wawasan dunia yang berbeda dari dunia. Wawasan dunia yang melawan Allah harus ditransformasi menjadi wawasan dunia Kristen yang disesuaikan pada prinsip-prinsip Firman.

Pola hidup berbeda dari dunia memprasyaratkan transformasi wawasan dunia, karena melaluinya orang Kristen dimampukan untuk membedakan kehendak Allah dari prinsip-prinsip yang bertentangan dengannya (Rm. 12:2). Transformasi wawasan dunia juga memungkinkan sikap kritis terhadap budaya karena realita dipertimbangkan secara Kristen dan disesuaikan pada prinsip-prinsip Firman (Boice, 2005, p. 1539-1540). Orang Kristen tidak hanya mengalami keselamatan tapi juga mengalami transformasi hidup berdasarkan transformasi wawasan dunia.

Pemisahan diri dari budaya bukan ekspresi transformasi wawasan dunia. Transformasi wawasan dunia tampak melalui transformasi hidup, di mana 
orang Kristen tidak lagi menjadikan prinsip-prinsip budaya sebagai paradigma yang kepadanya realita (termasuk prinsip-prinsip Firman) disesuaikan. Sebaliknya totalitas realita disesuaikan pada Firman. Seluruh dimensi hidup dipahami berdasarkan prinsip-prinsip Firman (Jones, 2013, p. 2). Hasilnya adalah kehidupan Kristen atau spiritualitas yang benar.

\section{Mengusahakan Transformasi Biblikal dan Moderat melalui Pembinaan Warga Gereja}

Melalui Roma 12:1-2 dan Filipi 4:8-9 Paulus menegaskan transformasi biblikal dan moderat, di mana segala sesuatu disesuaikan jemaat pada wawasan dunia Kristen, sebagai arah pembinaan warga gereja. Melaluinya transformasi ini unsur-unsur budaya yang tidak sesuai Firman dapat dihindari, sedangkan unsur-unsur yang sesuai Firman diakomodir dan dihidupi bersama prinsip-prinsip Kristen lainnya.

Gereja-gereja di Sumba ditantang untuk memikirkan pembinaan yang menghasilkan transformasi wawasan dunia, yang bermuara pada transformasi hidup jemaat dan budaya sesuai Firman Tuhan. Jemaat harus mengalami transformasi wawasan dunia sehingga dapat memahami segala sesuatu (termasuk budaya) berdasarkan wawasan dunia Kristen, bukan sebaliknya.

\section{Penanaman Prinsip-Prinsip Kristen yang Biblikal}

Telah dijelaskan bahwa wawasan dunia terbentuk dari sejumlah prinsip yang diyakini kebenarannya. Maka pembentukan wawasan dunia warga gereja tidak dapat tidak melibatkan penanaman prinsip-prinsip Firman yang mendasari iman Kristen. Hal inilah ditunjukkan Paulus dalam Roma 1-11. Ia memberi prinsip-prinsip iman Kristen untuk mengubah cara pikir jemaat. Hal yang sama dilakukannya dengan mengarahkan jemaat untuk memikirkan halhal mulia, adil dan suci (Flp. 4:8).

Telah ditunjukkan pula bahwa sebagian orang Kristen Sumba masih meyakini perinsip-prinsip Marapu. Sebab itu pembinaan warga gereja perlu menekankan pengajaran yang kokoh secara teologis dan yang memiliki fondasi biblikal memadai. Ini adalah titik awal dari usaha menanamkan prinsipprinsip biblikal dalam kognisi warga gereja.

Penanaman prinsip-prinsip Kristen tidak hanya diusahakan melalui pengajaran yang berulang dan kreatif. Gereja juga perlu mengargumentasikan pengajarannya secara meyakinkan. Tujuannya adalah jemaat tidak hanya memperoleh pengertian tentang prinsip-prinsip imannya, tapi juga meyakini kebenaran dan supremasi Firman atas prinsip-prinsip Marapu yang dihidupi sebelumnya.

Pemahaman dan keyakinan terhadap prinsipprinsip Kristen memberi kepekaan dan kemampuan, pada jemaat, untuk menguji prinsip-prinsip yang ditawarkan baik oleh Marapu maupun prinsip-prinsip lainnya, yang dijumpai dalam keseharian.

\section{Mendorong Regularisasi Prinsip-Prinsip Kristen} yang Biblikal melalui Praktik Hidup

Telah ditunjukkan pula bahwa wawasan dunia tidak hanya terbentuk berdasarkan prinsip-prinsip yang diyakini, tapi juga melibatkan regularisasi prinsip tersebut dalam praktik hidup. Gereja di Sumba perlu memperhatikan dimensi praktis ini, karena sebagian orang Kristen Sumba - sebagaimana dijelaskan sebelumnya - masih mempraktikkan kehidupan yang berciri Marapu.

Paulus menjadikan prinsip-prinsip dalam Roma 1-11 sebagai fondasi kehidupan Kristen yang dinasehatkan dalam pasal 12-16. Hal yang sama dilakukannya dalam Filipi 4:9. Palus kemudian mendorong jemaat untuk terus-menerus menerapkan atau menghidupi prinsip-prinsip tersebut secara praktis (regularisasi prinsip dalam tindakan).

Pembinaan warga gereja di Sumba tidak dapat berhenti pada pengajaran. Gereja perlu memikirkan strategi yang tepat agar pengajaran teologis dan biblikal membentuk kehidupan atau spiritualitas Kristen yang berkualitas, yang tampak dalam kehidupan nyata. Tahapan ini penting karena perubahan dari praktik hidup yang disesuaikan pada prinsipprinsip Marapu menjadi praktik hidup yang diarahkan oleh prinsip-prinsip Kristen adalah petunjuk pada perubahan komitmen religius. Selain itu peru- 
bahan komitmen religius adalah petunjuk terkuat pada perubahan wawasan dunia.

Regularisasi prinsip-prinsip Kristen dalam tindakan menjauhan jemaat dari regularisasi tindakan yang disesuaikan pada prinsip-prinsip budaya yang melawan Firman. Regularisasi juga mengakarkan prinsip-prinsip tersebut dalam kognisi, memperkuat wawasan Kristen dan mempertajam kepekaan dan kemampuan untuk menguji budaya.

\section{Transformasi Biblikal dan Moderat}

Fokus gereja dalam pembinaan warganya bukan kontekstualisasi tapi transformasi budaya yang biblikal dan moderat. Jika transformasi seperti ini akan melibatkan kontekstualisasi yang biblikal. Transformasi dapat diusahakan juga melalui penelitian teologis dan biblikal terhadap unsur-unsur budaya Marapu. Penelitian dapat dimulai dari unsurunsur budaya yang masih melekat dalam keseharian orang Sumba. Ini dilakukan untuk menentukan unsur-unsur yang harus ditolak dan yang dapat diakomodir orang Kristen. Hasil penelitian disosialisasikan pada jemaat melalui pengajaran dan argumentasi yang menunjukkan supremasi iman Kristen atas budaya.

Pengertian dan keyakinan yang benar, yang diperoleh melalui pembinaan warga gereja, memungkinkan jemaat secara sukarela meninggalkan budaya yang tidak biblikal dan menyesuaikan hidup pada prinsip-prinsip Kristen. Dengan demikian, transformasi biblikal dan moderat menjangkau kehidupan jemaat secara personal.

Dengan jumlah orang Kristen Sumba yang mencapai lebih dari 400.000 jiwa (mayoritas), pembinaan warga gereja yang berhasil akan menghasilkan kesaksian hidup Kristen yang berdampak signifikan pada perubahan budaya. Melaluinya transformasi biblikal dan moderat menjangkau masyarakat dan budaya di Sumba.

\section{KESIMPULAN}

Wawasan dunia Marapu adalah kekuatan utama penentu komitmen religius orang sumba ter- hadap Marapu. Wawasan dunia tersebut membentuk interpretasi dan respons, bahkan perlawanan terhadap Injil. Sebab itu wawasan dunia Marapu merupakan tantangan bagi pembinaan warga gereja di Sumba. Keyakinan terhadap prinsip-prinsip Marapu dan regularisasinya melalui praktik hidup tidak hanya membentuk tapi juga memperkuat posoi dan peran wawasan dunia Marapu dalam kehidupan orang Sumba, termasuk sebagian orang Kristen.

Akibatnya unsur-unsur yang asing bagi $\mathrm{Ma}$ rapu, seperti iman Kristen, diinterpretasi dan disesuaikan pada prinsip-prinsip Marapu (paradigma dalam memahami realita dan protokol penentu respons terhadap realita). Hal ini membuat prinsip-prinsip iman Kristen dapat ditolak atau diakomodir untuk memperkuat wawasan dunia Marapu. Hasilnya adalah sinkretisme dan spiritualitas Kristen yang berciri Marapu.

Gereja ditantang untuk melakukan pembinaan warga gereja, yang menghasilkan perubahan komitmen religius bahkan transformasi budaya. Nasihat Paulus dalam Roma 12:1-2 dan Filipi 4:8-9 merupakan petunjuk untuk menjawab tantangan tersebut. Dalam dua teks tersebut, Paulus menjadikan transformasi wawasan dunia sebagai solusi. Pembinaan warga gereja harus diarahkan pada pembentukan pembentukan wawasan dunia Kristen, yang mengganti peran wawasan dunia Marapu. Ini menghasilkan jemaat dewasa yang berpikir secara Kristen, menghidupi spiritualitas Kristen dan mampu berpikir kristis terhadap budaya.

Wawasan dunia terbentuk karena ada prinsip-prinsip yang diyakini dan diregularisasi dalam praktik hidup. Sebab itu gereja perlu memberi pengajaran teologis dan biblikal pada jemaat. Gereja juga harus meneliti prinsip-prinsip budaya yang membentuk pikiran danpraktik hidup jemaat. Melaluinya unsur-unsur budaya yang harus dieliminasi dan diakomidir dapat ditentukan.

Pengajaran biblikal dan hasil observasi dapat disosialisasikan atau diajarkan dalam berbagai wadah pembinaan warga gereja di Sumba seperti khotbah, katekasasi dan berbagai bentuk pelayanan 
lainnya. Setelah prinsip yang benar diajarkan, gereja mendorong regularisasi prinsip-prinsip tersebut dalam kehidupan jemaat.

Harus diakui bahwa penelitian ini terbatas karena berfokus pada dua hal: wawasan dunia $\mathrm{Ma}$ rapu sebagai tantangan dalam pembinaan warga ge-

\section{DAFTAR RUJUKAN}

Alybina, T. (2014). Vernacular Beliefs and Official Traditional Religion: The Position and Meaning of the Mari Worldview in the Current Context. Approaching Religion, 4(1), 89-100.

Anderson, L. (2010). Theology of Culture and Context of Community. The Journal of the Evangelical Homiletics Society, 10(1), 4-17.

Boice, J. M. (2005). Romans: The New Humanity Vol.4. Grand Rapids, Michigan: Baker Books.

Bruning, S. D., \& Lambe, K. E. (2009). Linking worldview, relationship attitudes, and behavioral outcomes: Implications for the study and practice of public relations. Journal of Promotion Management, 14(34), 139-151. https://doi.org/10.1080/ 10496490802620313.

Carson, D. A. (2018). Kristus dan Kebudayaan: Sebuah Kajian Baru. Surabaya: Penerbit Momentum.

Demeter, T. (2012). "Weltanschauung" as a priori: sociology of knowledge from a 'romantic' stance. Studies in East European Thought, 64(1), 39-52. Retrieved from https://www.jstor.org/stable/41477748

Denscombe, M. (2014). The Good Research Guide: For Small-Scale Social Research Projects. New York: Open University Press.

Dwiraharjo, S. (2018). Persembahan yang Hidup Sebagai Buah dari Pembenaran Oleh Iman Menurut Roma 12:1-2. Prudentia: Jurnal Teologi Dan Pendidikan Kristiani, 1(1), 124.

Holloway, P. A. (1998). Bona Cogitare: An reja di Sumba dan transformasi wawasan dunia sebagai tujuan pembinaan warga gereja. Tidak ada diskursus mengenai strategi konkret gereja dalam mengusahakan transformasi wawasan dunia. Namun ini merupakan ruang yang dapat dilengkapi melalui penelitian-penelitian lebih lanjut.

Epicurean Consolation in Phil 4:8-9. Harvard Theological Review, 91(1), 89-96. https://doi.org/10.1017/s0017816000006465

Immanuel, J. M. (2013). Marapu dalam Bencana Alam: Pemaknaan dan Respons Masyarakat Wunga Sumba Timur Indonesia. Yogyakarta: Center for Religious and CrossCultural Studies.

Jones, T. P. (2013). Editorial: How a Biblical WoHdview Shapes the Way We Teach • vr Children. The Journal of Discipleship and Family Ministry, 4(1), 2-4.

Kamuri, J. P. (2020). Menimbang Posisi Penganut Marapu di Hadapan Pemerintah Negara Republik Indonesia. Societas Dei: Jurnal Agama Dan Masyarakat, 7(1), 73-98. https://doi.org/https://doi.org/10.33550/sd.v7 i1.129

Kleden, D. (2017). Belis dan harga seorang perempuan Sumba (Perkawinan adat suku Wewewa, Sumba Barat Daya, NTT). Jurnal Studi Budaya Nusantara, 1(1), 56-70.

Lado, R. R. R. T., \& Palar, M. R. A. (2019). Marapu' Indigenous Belief System in Sumba. In J. M. I. Sormin (Ed.), Masyarakat Adat: Pengakuan Kembali, Identitas dan Keindonesiaan (pp. 107-113). Jakarta: BPK Gunung Mulia.

Laugrand, F. (2012). The Transition to Christianity and Modernity among Indigenous Peoples. Reviews in Anthropology, 41(1), 1-22. https://doi.org/10.1080/00938157.2012.6449 96

MacDonald, M. N. (2011). The primitive, the primal, and the indigenous in the study of 
religion. Journal of the American Academy of Religion, 79(4), 814-826. Retrieved from https://www.jstor.org/stable/41348740

Natar, A. N. (2019). Penciptaan dalam Perspektif Sumba: Suatu Upaya Berteologi Ekologi Kontekstual. GEMA TEOLOGIKA: Jurnal Teologi Kontekstual Dan Filsafat Keilahian, 4(1), 101-120. https://doi.org/10.21460/ gema.2019.41.428

Niebuhr, R. (1953). Christ and Culture. New York: Harper \& Row, Publishers, Inc.

Nugroho, W. A. (2018). Peranan Pendidikan Keluarga Tentang Kekudusan Hidup Menurut Roma 12:1-2. FIDEI: Jurnal Teologi Sistematika Dan Praktika, 1(2), 185-198.

https://doi.org/10.34081/fidei.v1i2.16

Owens, T. J., Robinson, D. T., \& Smith-lovin, L. (2010). Three Faces of Identity. 36, 477499. Retrieved from https://www.jstor.org/ stable/25735088

Patterson, P. (2012). Encountering Culture in Light of The Book of Daniel. Southwestern Journal of Theology, 55(1), 52-62.

Schilbrack, K. (2013). What Isn't Religion? The Journal of Religion, 93(3), 291-318. Retrieved from https://www.jstor.org/ stable/10.1086/670276

Schultz, K. G., \& Swezey, J. A. (2013). A ThreeDimensional Concept of Worldview. Journal of Research on Christian Education, 22(3), 227-243. https://doi.org/10.1080/ 10656219.2013.850612

Smiga, G. (1991). Romans 12:1-2 and 15:30-32 and the Occasion of the Letter to the Romans. The Catholic Biblical Quarterly,
53(2), 257-273. Retrieved from https://www.jstor.org/stable/43719526

Snyman, A. . (2007). Philippians 4: 1-9 from a rhetorical perspective. Verbum et Ecclesia, 28(1), 224-243.

Soeriadiredja, P. (2013). Marapu: Konstruksi Identitas Budaya Orang Sumba, NTT. Jurnal Antropologi Indonesia, 34(1), 59-73.

Sumarto, Y. (2019). Tinjauan Teologis Tentang Ibadah Bagi Pelaksanaan Misi Allah. Jaffray, 17(1), 57-72. https://doi.org/ $10.25278 / \mathrm{jj} . v 17 \mathrm{i} 1.312$

Vaisey, S., \& Lizardo, O. (2010). Can Cultural Worldviews Influence Network Composition? Social Forces, 88(4), 15951618. Retrieved from https://www.jstor.org/stable/40645951

Vel, J. A. . (2008). Uma Politics: An Ethnography of Democratization in West Sumba, Indonesia, 1986-2006. Leiden: KITLV Press.

Webb, R. A. F. P. (1986). Adat and Christianity in Nusa Tenggara Timur: Reaction and Counteraction: Traditional custom and modern development in Eastern Indonesia. Philippine Quarterly of Culture and Society, 14(4), 339-365. Retrieved from https://www.jstor.org/stable/29791907

Wellem, F. D. (2004). Injil dan marapu: Suatu Studi Historis Teologis tentang Perjumpaan Injil dengan Masyarakat Sumba pada Periode 1876-1990. Jakarta: BPK Gunung Mulia.

Yarnell III, M. B. (2012). Global Choices for Twenty-First Century Christians : Bringing Clarity to Missional Theology. Southwestern Journal Of Theology, 55(1), 18-36. 